\title{
Nano-size effect of Au catalyst for electrochemical reduction of oxygen in alkaline electrolyte
}

\author{
ZHANG Gui-Rong, XU Bo-Qing* \\ Innovative Catalysis Program, Key Lab of Organic Optoelectronics \& Molecular Engineering, Department of Chemistry, Tsinghua University, \\ Beijing 100084, China
}

A R T I C L E I N F O

Article history:

Received 11 January 2013

Accepted 15 February 2013

Published 20 May 2013

\section{Keywords:}

Au nanoparticle

Size effect

Oxygen reduction reaction

Surface electronic structure

Alkaline electrolyte

\begin{abstract}
A B S T R A C T
Oxygen reduction reaction (ORR) in alkaline electrolyte $(0.5 \mathrm{~mol} / \mathrm{L} \mathrm{KOH})$ was studied on a series of carbon supported Au nanoparticles (NPs) with average sizes ranging from 3 to $14 \mathrm{~nm}$, using the rotating disk electrode methods. Downsizing the Au NPs from 14 to $3 \mathrm{~nm}$ resulted in continued enhancement in both the intrinsic and mass-specific activity of Au for ORR but produced no influence on the reaction mechanism or number of transferred electrons per $\mathrm{O}_{2}$-reduction. Careful analyses of the particle shapes of Au NPs with varied sizes by using high-resolution transmission electron microscopy enabled us to estimate the fraction of surface $\mathrm{Au}$ atoms at different positions or coordination (energy) state. Correlating the fraction of high energy surface atoms with the Au activity for ORR disclosed the importance of high energy surface atoms in enhancing the intrinsic activity of $\mathrm{Au}$. Fundamental correlation between the Au intrinsic activity for ORR and the experimentally determined surface electronic structure of Au NPs was also established.
\end{abstract}

(C) 2013, Dalian Institute of Chemical Physics, Chinese Academy of Sciences. Published by Elsevier B.V. All rights reserved.

\section{Introduction}

The electrochemical reduction of oxygen (oxygen reduction reaction, ORR) is a reaction of tremendous interest both for basic and applied research [1-5]. It constitutes the cathode reaction in polymer electrolyte membrane fuel cells as well as in chlorine electrolysis using oxygen depolarized cathodes, and is of importance to the corrosion phenomena [1-3]. Gold was found reasonably active for ORR in alkaline electrolyte [6-9]. The use of $\mathrm{Au}$ nanoparticles (NPs) for ORR has attracted increasing attention in recent years due to their distinctly different catalytic properties from bulk $\mathrm{Au}[8,10-15]$. One of the intensively debated issues in this field is concerned with the size-dependent catalytic activity of Au NPs for ORR, especially when the size or diameter of Au NPs is reduced to the sub-10 nanometer region where the Au NPs are theoretically predicted to have enhanced electron density near the Fermi level, narrowed d-band and higher-lying d-band center energy relative to bulk Au [16-18]. Besides, the coordination state of surface atoms and the fractions of surface atoms at different locations (corners, edges, (111) and (100) facets) would also change with the Au particle sizes [16]. As ORR features a strongly structure-sensitive chemistry, uncovering how the size-dependent surface electronic/geometric structure of $\mathrm{Au}$ could affect its catalysis towards ORR would have significant implications not only for better understanding the size effect of $\mathrm{Au}$ in electrocatalysis but also for the design and optimization of new cathode catalysts.

Previous studies on electrocatalysis of Au NPs for ORR in alkaline electrolyte were documented with inconsistent obser-

\footnotetext{
*Corresponding author. Tel: +86-10-62792122; Fax: +86-10-62771149; E-mail: bqxu@mail.tsinghua.edu.cn This work was supported by the National Natural Science Foundation of China (21033004) and the National Basic Research Program of China (2013CB933103). 
vations on the $\mathrm{Au}$ nanosize effect $[8,11,12,19]$. Smaller Au NPs showed higher activity for ORR in Refs. [8] and [11] but were found less active in Refs. [12] and [19]. In these previous reports, Au NPs with varied sizes were synthesized via colloidal methods by varying the nature and/or dosage of the stabilizer molecules. The variations in the stabilizers (nature and dosage) could heavily distort the size-dependent catalytic behavior of $\mathrm{Au}$ NPs [20,21]. We also showed earlier that a change in the nature of the stabilizer molecules could cause an influence that even significantly outweighs the Au nano-size effect in electrocatalysis [15]. The discrepancy in previous literature on the size-dependent activity of Au NPs for ORR may therefore arise from an ignored effect of the stabilizers involved in the colloidal synthesis of the Au NPs. To better address the size-dependent catalytic activity of Au NPs, it would be essential to prepare differently sized Au NPs without varying the nature of the stabilizer molecules.

This work aims to clarify how the catalytic activity of Au NPs for ORR would change with variations in their particle size and surface structure by carefully measuring the $\mathrm{Au}$ NPs using transmission electron microscopy/high-resolution transmission electron microscopy (TEM/HRTEM) and valence band $\mathrm{X}$-ray photoelectron spectroscopy (XPS). We report the size effect on the electrocatalytic properties of nearly monodisperse $\mathrm{Au}$ NPs, with the data obtained on a series of Au NP samples whose average sizes range from 3.4 to $14.0 \mathrm{~nm}$. Our samples of $\mathrm{Au}$ NPs were synthesized by using polyvinylpyrrolidone (PVP) as the only stabilizer in order to exclude possible interferences from using different stabilizers. We show that smaller Au NPs are intrinsically more active for ORR in alkaline electrolyte. Moreover, for the first time, we disclose that $\mathrm{Au}$ activity for ORR correlates well with the experimentally determined surface electronic structure (d-band center energy).

\section{Experimental}

\subsection{Synthesis of $A u-d$ and carbon supported $A u-d(A u-d / C)$ samples}

Nearly monodisperse Au- $d(d=3.2-14.0 \mathrm{~nm}$, which denotes the average particle diameter) NPs were synthesized by using a seed-mediated growth method using Au NPs in diameters of $1.9 \pm 0.4 \mathrm{~nm}$ as the primary seeds, as documented previously $[22,23]$. Au- $d / \mathrm{C}$ samples were prepared by mixing a desired amount of Vulcan XC-72 carbon black (BET surface area: 240 $\mathrm{m}^{2} / \mathrm{g}$, Cabot Company) with as-synthesized Au- $d$ hydrosols, followed by a careful adjustment of solution acidity to $\mathrm{pH}=1.5$ with $1 \mathrm{~mol} / \mathrm{L} \mathrm{HNO}_{3}$ solution. The suspension was then refluxed for $2 \mathrm{~h}$ under vigorous stirring. The solid was separated by filtration, followed by intensively washing with deionized water and air-drying at $110^{\circ} \mathrm{C}$ for $2 \mathrm{~h}$ to give $\mathrm{Au}-\mathrm{d} / \mathrm{C}$ samples.

\subsection{Structural analysis}

TEM images were captured using a JEOL JEM-2010 microscope operated at $120 \mathrm{kV}$. HRTEM images were obtained on a FEI Tecnai G2 F20 U-TWIN microscope at $200 \mathrm{kV}$ accelerating voltage. The samples were prepared by placing a drop of catalyst powder in deionized water on a Formvar/carbon film coated $\mathrm{Cu}$ grid (3 mm, 300 mesh), followed by drying under ambient conditions. High resolution valence band XPS measurements were carried out on an ESCALAB 250 (VG Thermo ${ }^{\mathrm{TM}}$ ) high performance electron spectrometer equipped with a monochromated $\mathrm{Al} K_{\alpha} \mathrm{X}$-ray radiation (1484.6 eV). The binding energies were measured with an accuracy of $\pm 0.1 \mathrm{eV}$ and are given with respect to the Au Fermi edge $\left(E_{\mathrm{f}}\right)$ assuming $E_{\mathrm{f}}=0 \mathrm{eV}$. The loading amount of Au was set at $5 \mathrm{wt} \%$ for all $\mathrm{Au}-d / \mathrm{C}$ samples and was later determined by inductively coupled plasma-atomic emission spectroscopy (ICP-AES, IRIS Intrepid II XSP, ThermoFisher).

\subsection{Electrochemical characterization}

Electrochemical measurements were performed on a potentiostat/galvanostat model 263A (PAR) controlled by PowerSuite software [24-26]. A saturated calomel electrode (SCE) and a Pt wire (diameter: $0.5 \mathrm{~mm}$ ) were used as the reference and counter electrodes, respectively. All potentials reported in this work are given with respect to SCE. Unless otherwise specified, the ORR measurements were performed in $\mathrm{O}_{2}$-saturated $0.5 \mathrm{~mol} / \mathrm{L} \mathrm{KOH} \mathrm{(Au-d/C)} \mathrm{electrolyte} \mathrm{using} \mathrm{a} \mathrm{glassy} \mathrm{carbon} \mathrm{ro-}$ tating disk electrode (GC-RDE, $0.196 \mathrm{~cm}^{2}$, Pine Research Instrumentation) at a rotation rate of $1600 \mathrm{r} / \mathrm{min}$. The linear sweeping voltammetry (LSV) measurement was conducted at room temperature at a scanning rate of $10 \mathrm{mV} / \mathrm{s}$. Before the preparation of the working electrode, the GC-RDE was polished to a mirror finish using 0.5 and $0.05 \mu \mathrm{m}$ alumina powder. A catalyst ink was prepared by sonicating a suspension of the catalyst $(5.0 \mathrm{mg})$ in isopropanol $(1.0 \mathrm{ml})$, and then $10 \mu \mathrm{l}$ of the suspension was transferred onto the GC-RDE electrode. After solvent evaporation, $10 \mu \mathrm{l}$ of Nafion solution $(0.05 \mathrm{wt} \%$, DuPont Company) was cast on the disk to attach the catalyst. Prior to each measurement, the electrolyte was purged by bubbling with high purity nitrogen or oxygen for $15 \mathrm{~min}$. A gentle nitrogen or oxygen flow was then kept to avoid disturbance from ambient atmosphere during the measurement.

The kinetic current was used to compare the catalytic activity of the Au- $d / \mathrm{C}$ catalysts, which was obtained according to the Koutecky-Levich (K-L) equation [27]. The mass-transport corrected kinetic current $\left(i_{\mathrm{k}}\right)$ was calculated based on the equation $i_{\mathrm{k}}=i \times i_{\mathrm{d}} /\left(i_{\mathrm{d}}-i\right)$, where $i$ is the experimentally measured current, and $i_{\mathrm{d}}$ is the diffusion-limiting current.

To compare the size-dependent catalytic activity of Au-d/C catalysts, the kinetic currents were normalized according to both the Au loadings to obtain the mass-specific activity (MSA) and the electrochemically active $\mathrm{Au}$ surface areas (EAS) to measure the intrinsic activity (IA). The electrochemically active $\mathrm{Au}$ surface areas were determined by using the method of Trasatti and Petrii [28].

\section{Results and discussion}

Six samples of nearly monodisperse Au NPs, $1.9 \pm 0.4,3.2 \pm$ $0.5,4.7 \pm 0.7,8.0 \pm 1.3,10.3 \pm 0.8$, and $14.0 \pm 1.9 \mathrm{~nm}$, were syn- 

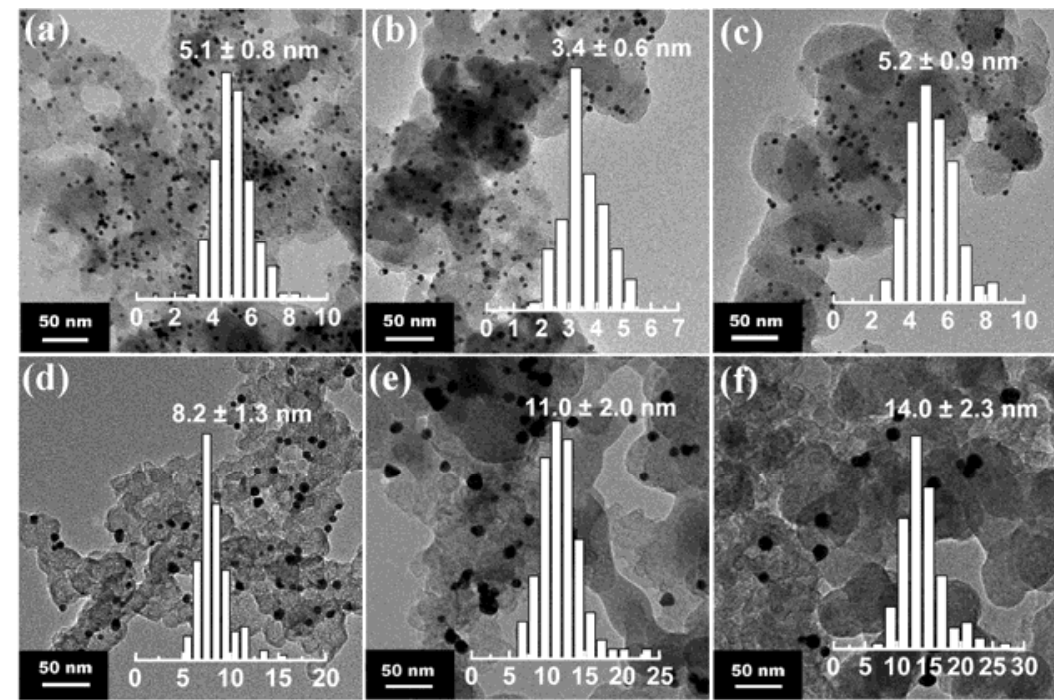

Fig. 1. Representative TEM images and their corresponding size histograms for $A u$ NPs in $A u-1.9 / C(a), A u-3.2 / C(b), A u-4.7 / C(c), A u-8.0 / C$ (d), $\mathrm{Au}-10.3 / \mathrm{C}(\mathrm{e})$, and $\mathrm{Au}-14.0 / \mathrm{C}$ (f) samples.

Table 1

Physicochemical and catalytic properties of Au-d/C samples for ORR in alkaline electrolyte.

\begin{tabular}{lcccccccc}
\hline Sample & Au loading $(\mathrm{wt} \%)$ & \multicolumn{1}{c}{$d_{\mathrm{Au}} / \mathrm{nm}$} & $\mathrm{EAS}\left(\mathrm{m}^{2} / \mathrm{g}_{\mathrm{Au}}\right)$ & $E_{\text {onset }} / \mathrm{V}$ & $E_{1 / 2} / \mathrm{V}$ & $\mathrm{MSA}\left(\mathrm{A} / \mathrm{g}_{\mathrm{Au}}\right)$ & $\mathrm{IA}\left(\mathrm{A} / \mathrm{m}_{\mathrm{Au}}{ }^{2}\right)$ & $\mathrm{Tafel} \mathrm{slope}(\mathrm{mV} / \mathrm{dec})$ \\
\hline $\mathrm{Au}-1.9 / \mathrm{C}$ & 4.1 & $5.1 \pm 0.8$ & 14.2 & -0.12 & -0.27 & 58.0 & 4.1 & 143 \\
$\mathrm{Au}-3.2 / \mathrm{C}$ & 4.0 & $3.4 \pm 0.6$ & 16.4 & -0.12 & -0.24 & 124.6 & 7.6 & 125 \\
$\mathrm{Au}-4.7 / \mathrm{C}$ & 5.2 & $5.2 \pm 0.9$ & 14.8 & -0.12 & -0.25 & 102.4 & 6.9 & 130 \\
$\mathrm{Au}-8.0 / \mathrm{C}$ & 5.0 & $8.2 \pm 1.3$ & 13.9 & -0.12 & -0.24 & 80.6 & 5.8 & 146 \\
$\mathrm{Au}-10.3 / \mathrm{C}$ & 5.9 & $11.0 \pm 2.0$ & 11.4 & -0.12 & -0.25 & 62.8 & 5.5 & 142 \\
$\mathrm{Au}-14.0 / \mathrm{C}$ & 5.3 & $14.0 \pm 2.3$ & 7.8 & -0.13 & -0.26 & 38.9 & 5.0 & 137 \\
\hline
\end{tabular}

thesized in this work, and their detailed characterization data were given in our earlier publications [22,23]. Figure 1 shows the representative TEM images and their corresponding size distribution histograms for the carbon-supported Au- $d$ NPs. It can be seen that the Au NPs were separated fairly well on the carbon support without severe aggregation. The sizes and their distribution data were obtained by measuring randomly more than 300 particles in different TEM regions or images, which are summarized in Table 1. It is seen that the carbon supported $\mathrm{Au}-d$ NPs essentially maintained their original sizes before immobilization, with the only exception that the small $\mathrm{Au}$ seeds (Au-1.9) became significantly bigger (average size: $5.1 \mathrm{~nm}$ ) after the immobilization. The significant "growth" of these seed particles during the immobilization process could be due to their much higher surface energy, entitling them a significantly higher thermodynamic driving to grow bigger. As the Au loading was fixed at ca. $5 \mathrm{wt} \%$ for all Au- $d / \mathrm{C}$ samples, growth of the small $\mathrm{Au}$ seeds would also be favored kinetically because their smallest sizes would translate to the densest population (by number of Au particles) on their landing at the carbon support (Vulcan XC-72) surface, making easier of their ( $\mathrm{Au}-1.9)$ growth during the immobilization process, e.g., by Ostwald ripping [29].

The variation of metal particle size is always accompanied by a change in the metal particle shape, which would lead to variation in its catalytic property. It is well known that the change in metal particle shape would often be related with a change in the particle internal crystal structure (i.e., single or twinned crystals) [30]. A powerful tool to determine the internal crystal structure of a metal NP is the HRTEM technique, which discriminates single and twinned crystals according to their lattice fringe patterns [30-32]. Our earlier HRTEM measurements of the as-prepared Au- $d$ NPs disclosed that the primary $\mathrm{Au}$ seeds (Au-1.9) were $100 \%$ of single crystalline structure with a cuboctahedral shape (Fig. 2d) while the other Au- $d$ NPs $(d>3.2 \mathrm{~nm})$ were dominated by 5 -fold twinned structures in either icosahedral or decahedral shapes (Fig. 2d) [15,23]. In

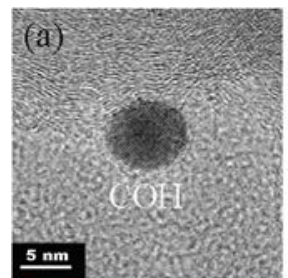

(d)

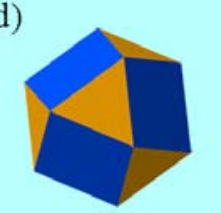

Cuboctahedron $(\mathrm{COH})$
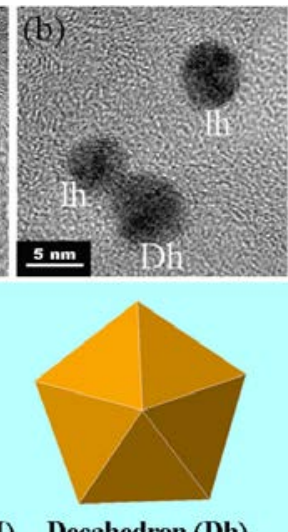

Decahedron (Dh)
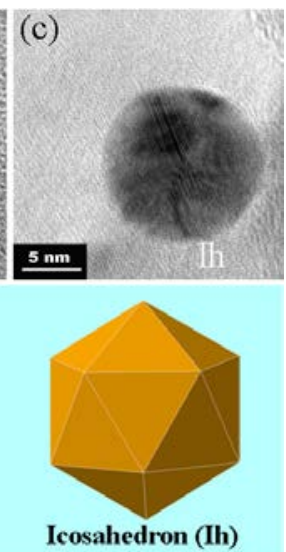

Fig. 2. Representative HRTEM images of $\mathrm{Au}$ NPs in $\mathrm{Au}-1.9 / \mathrm{C}$ (a), $\mathrm{Au}-4.7 / \mathrm{C}$ (b), and $\mathrm{Au}-10.3 / \mathrm{C}$ (c) samples. (d) shows the geometric models for Au cuboctahedron, decahedron, and icosahedron, and the dark (blue) and light (yellow) facets denote, respectively, the (100) and (111) planes at the particle surface. 
this study, we found that the immobilization of the as-prepared $\mathrm{Au}-d$ NPs onto carbon black imposed little effect on their internal crystal structures or particle shapes (Fig. 2); those Au NPs grown from the Au-1.9 seeds particles during their immobilization (i.e., in $\mathrm{Au}-1.9 / \mathrm{C}$ ) even preserved their single crystalline structure of the original $\mathrm{Au}$ seeds, as exemplified in Fig. 2a. Thus, another reason for our observed insignificant growth of the Au NPs in all the other Au- $d / C$ samples $(d \geq 3.2 \mathrm{~nm})$ could be that the majority (> 80\%) [23] of these Au NPs were already in their lowest surface energy states before they were immobilized as the five-fold twinned Au icosahedra and decahedra are enclosed exclusively with the densest $\mathrm{Au}$ (111) facets of the lowest surface energy [33].

The catalytic behavior of the Au- $d / \mathrm{C}$ catalysts for ORR was evaluated using LSV technology on a RDE. Figure 3a shows the polarization curves of the LSVs for ORR in $\mathrm{O}_{2}$-saturated 0.5 $\mathrm{mol} / \mathrm{L} \mathrm{KOH}$ solution, and the currents were normalized to the $\mathrm{Au}$ loadings. The shapes of the polarization curves are similar to those of the previous studies on $\mathrm{Au}$ catalysts for ORR $[12,19,34]$. Commencement of ORR on all the Au-d/C catalysts is indicated by the abrupt increase of current at $-0.12 \mathrm{~V}$ as the electrode potential was applied from positive to negative. As it would be expected, the reduction current increased with decreasing potential [24], and the region of mixed kinetic-diffusion control $(-0.1$ to $-0.4 \mathrm{~V})$ was followed at lower potentials by a mass-transport (diffusion) control region [34].

The IA and MSA data in Table 1 quantitatively show the calibrated $\mathrm{Au}$ activity data at $-0.25 \mathrm{~V}$. It appears that both the IA and MSA data strongly correlate with the sizes of the Au NPs. Except for the $\mathrm{Au}-1.9 / \mathrm{C}$ sample, the smaller $\mathrm{Au}$ NPs always produced higher IA and MSA numbers for ORR. For instance, $\mathrm{Au}-3.2 / \mathrm{C}\left(7.6 \mathrm{~A} / \mathrm{m}_{\mathrm{Au}^{2}}\right)$ is 1.5 times more active than $\mathrm{Au}-14.0 / \mathrm{C}$ $\left(5.0 \mathrm{~A} / \mathrm{mAu}^{2}\right)$ by the IA data, demonstrating a faster ORR kinetics on smaller Au NPs. As smaller Au NPs had better exposure (higher dispersion or larger specific surface area), the enhancement in MSA on downsizing the Au particle size became even more significant, making $\mathrm{Au}-3.2 / \mathrm{C}$ (124.6 A/g $\left.\mathrm{g}_{\mathrm{Au}}\right) 3.2$ times more active than $\mathrm{Au}-14.0 / \mathrm{C}\left(38.9 \mathrm{~A} / \mathrm{g}_{\mathrm{Au}}\right)$. To our surprise, the onset ( $\left.E_{\text {onset }}\right)$ and half-wave $\left(E_{1 / 2}\right)$ potentials on the Au- $d$ catalysts hardly changed with the Au particle size (Table 1) though smaller Au NPs were found intrinsically more active. These data clearly show the nano-size effect on the catalytic properties of Au NPs. To our knowledge, this is the first time to demonstrate the size-dependent catalytic activity of Au NPs for ORR in alkaline electrolyte without disturbance of using different stabilizers. It should be noted that, although the Au sizes in $\mathrm{Au}-1.9 / \mathrm{C}(5.1 \mathrm{~nm})$ were close to those in $\mathrm{Au}-4.7 / \mathrm{C}(5.2 \mathrm{~nm})$, the $\mathrm{Au}$ in $\mathrm{Au}-4.7 / \mathrm{C}$ showed a much higher activity for ORR than that in Au-1.9/C. The distinctively high activity of Au NPs in the $\mathrm{Au}-4.7 / \mathrm{C}$ catalyst may arise from their associated multi-twinned particle structures (Fig. 2b). The multi-twinned $\mathrm{Au}$ NPs in the Au-4.7/C catalyst would have abundant crystal boundary sites that are more active for ORR $[9,12]$.

Figure $3 \mathrm{~b}$ presents the mass transfer corrected Tafel plots for oxygen reduction in $0.5 \mathrm{~mol} / \mathrm{L} \mathrm{KOH}$ solution. The Tafel slope between -0.25 and $-0.35 \mathrm{~V}$ varied in the range of 125 to $150 \mathrm{mV} / \mathrm{dec}$ for the Au- $d / \mathrm{C}$ catalysts, as summarized in Table 1. These values are common for ORR on Au electrodes [13,34,35]. They would indicate that the mechanism of ORR on Au catalyst in alkaline electrolyte is independent of the Au particle size.

Moreover, the average number of transferred electrons for the reduction of an oxygen molecule is calculated from the slope of the Koutecky-Levich plot $(1 / B)[27]: 1 / i=1 / i_{\mathrm{k}}+1 / i_{\mathrm{d}}=$ $1 / i_{\mathrm{k}}+1 /\left(B \omega^{1 / 2}\right), B=0.2 N F c_{0} D^{2 / 3} v^{-1 / 6}$, where $i$ is the measured overall current density, $i_{\mathrm{k}}$ the kinetic component, $i_{\mathrm{d}}$ the diffusion component, $\omega$ the angular rotation speed of the electrode, $N$ the number of transferred electrons per oxygen molecules, $\mathrm{F}$ the Faraday constant, $c_{0}$ the concentration of dissolved $\mathrm{O}_{2}$ in bulk electrolyte, $D$ the diffusion coefficient of $\mathrm{O}_{2}$, and $v$ the kinematic viscosity of the electrolyte. By referring to Ref. [8] for all of these parameters, the slope for every $\mathrm{Au}-d / \mathrm{C}$ catalyst was determined (Fig. 4). The number of transferred electrons $(N)$ at $-0.3 \mathrm{~V}$ for every $\mathrm{Au}-\mathrm{d} / \mathrm{C}$ catalyst is plotted against the Au particle size in the inset of Fig. 4. Clearly, the number of transferred electrons $(N \approx 2)$ was independent of the $\mathrm{Au}$ particle size, which points to a predominant two-electron reduction process for ORR on all the Au- $d / \mathrm{C}$ catalysts in alkaline electrolyte $[8,13]$. Therefore, irrespective of the Au particle size, the electrochemical ORR in alkaline electrolyte would produce peroxide as the primary product over the Au catalysts.
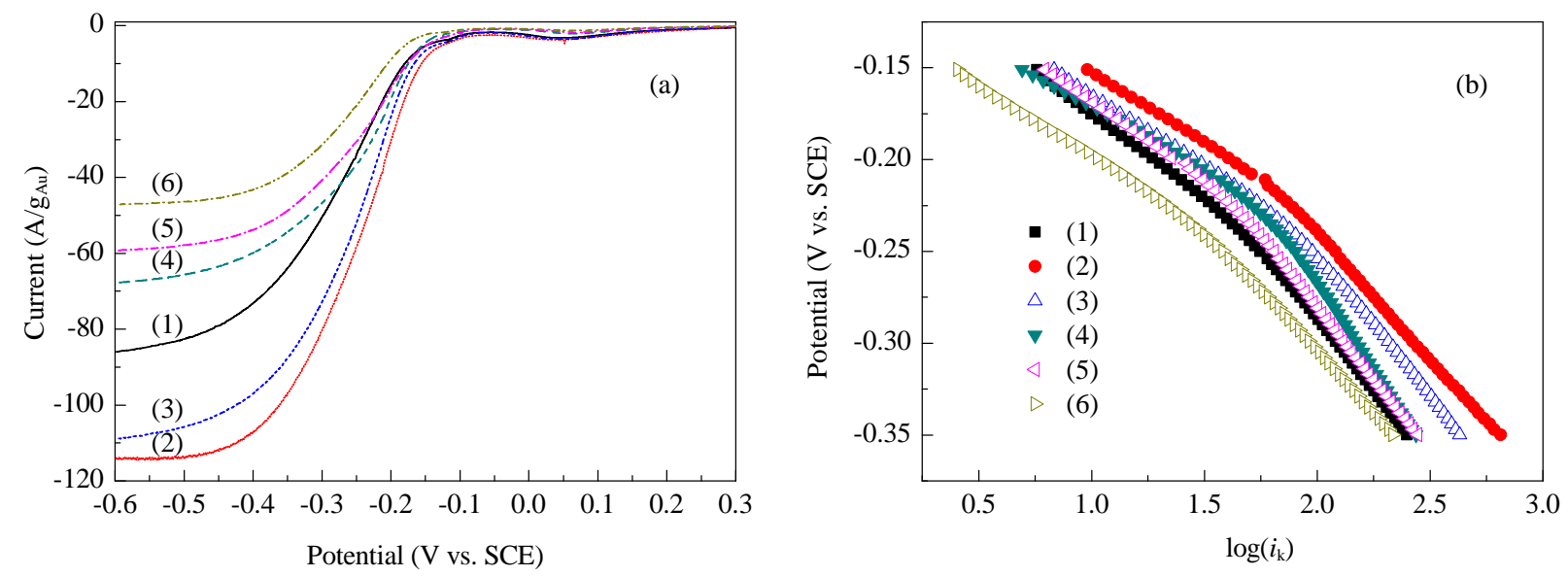

Fig. 3. (a) Polarization curves for ORR on Au-1.9/C (1), Au-3.2/C (2), Au-4.7/C (3), Au-8.0/C (4), Au-10.3/C (5), and Au-14.0/C (6) in $\mathrm{O}_{2}$-saturated 0.5 $\mathrm{mol} / \mathrm{L} \mathrm{KOH} \mathrm{solution;} \mathrm{(b)} \mathrm{Mass-transfer} \mathrm{corrected} \mathrm{Tafel} \mathrm{plots} \mathrm{for} \mathrm{ORR} \mathrm{on} \mathrm{Au-d/C} \mathrm{samples.} \mathrm{Scanning} \mathrm{rate:} 10 \mathrm{mV} / \mathrm{s}$; RDE rotation speed: $1600 \mathrm{r} / \mathrm{min}$. 


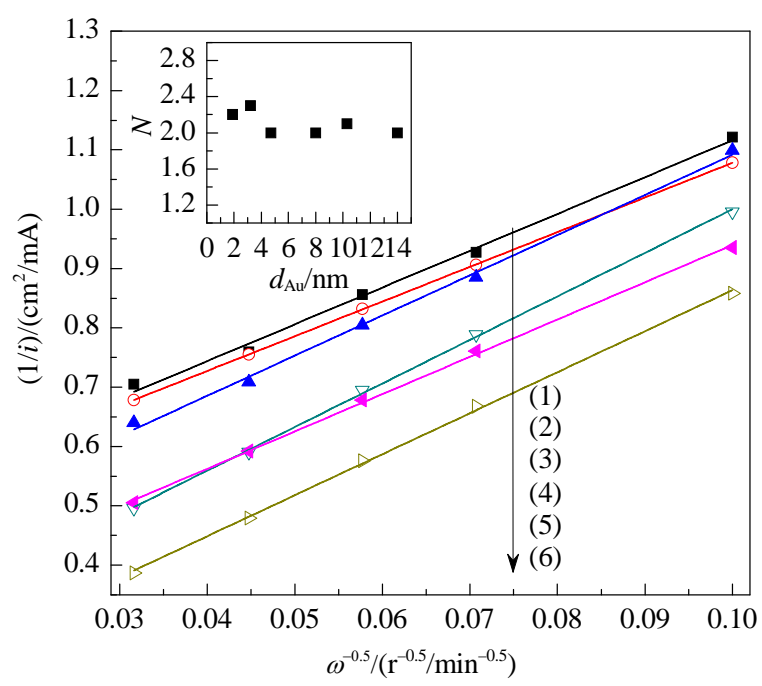

Fig. 4. Koutecky-Levich plots $(-0.30 \mathrm{~V})$ for ORR on $\mathrm{Au}-1.9 / \mathrm{C}(1)$, $\mathrm{Au}-3.2 / \mathrm{C}(2), \mathrm{Au}-4.7 / \mathrm{C}(3), \mathrm{Au}-8.0 / \mathrm{C}(4), \mathrm{Au}-10.3 / \mathrm{C}(5)$, and $\mathrm{Au}-14.0 / \mathrm{C}$ (6) catalysts in $\mathrm{O}_{2}$-saturated $0.5 \mathrm{~mol} / \mathrm{L} \mathrm{KOH}$ solution. The inset shows the average number of electrons transferred for the reduction of one oxygen molecule.

The above data demonstrate that the smaller Au NPs are intrinsically more active for ORR in alkaline electrolyte though the Au particle size imposed little effect on the oxygen reduction mechanism. Recalling that ORR on single crystal $\mathrm{Au}(h k l)$ is a strongly structure sensitive process in alkaline electrolyte, with the catalytic activity increasing in the order Au(111) < $\mathrm{Au}(110)<\mathrm{Au}(100)$ [36], we make attempt below to correlate the $\mathrm{Au}$ activity (IA) with specific surface Au sites, in a hope to understand how the Au activity toward ORR gets improved with downsizing Au NPs.

The distribution of specific surface atoms at different locations of a Au NP is mainly determined by the particle shape, or more exactly the internal crystal structure. As described in our earlier work [23], HRTEM technique can be used to determine internal crystal structures of Au NPs according to their characteristic lattice fringe patterns, which enabled us to further estimate the fraction of surface $\mathrm{Au}$ atoms at different locations (i.e., corners, edges, (111) and (100) facets). In specific, estimation of the fraction of surface $\mathrm{Au}$ atoms at (100) facets and edge/corner positions on Au NPs of varied sizes can be made based on the onion-like magic cluster models [37], i.e., a Au NP with a definite size is atomically constructed layer-by-layer. The particle size is dependent on the exact number of atomic layers (n); e.g. Au-1.9 nm would be composed of 3 atomic layers containing a total number of $147 \mathrm{Au}$ atoms (including the core atom). The Au NPs were classified into two classes according to analysis of the internal crystal structure of Au NPs by HRTEM: single crystals (treated as cuboctahedra) and five-fold twinned crystals (treated as icosahedra). Taking into consideration of the internal crystal structure (shape) selectivity of the Au NPs, the fraction of surface Au atoms at corner, edge, and (100) facets can thus be determined according to the formulas illustrated in Fig. 5 for the cuboctahedral and icosahedral particles. As the atoms at different positions can be discriminated essentially by coordination numbers (CNs), we divided the surface at-

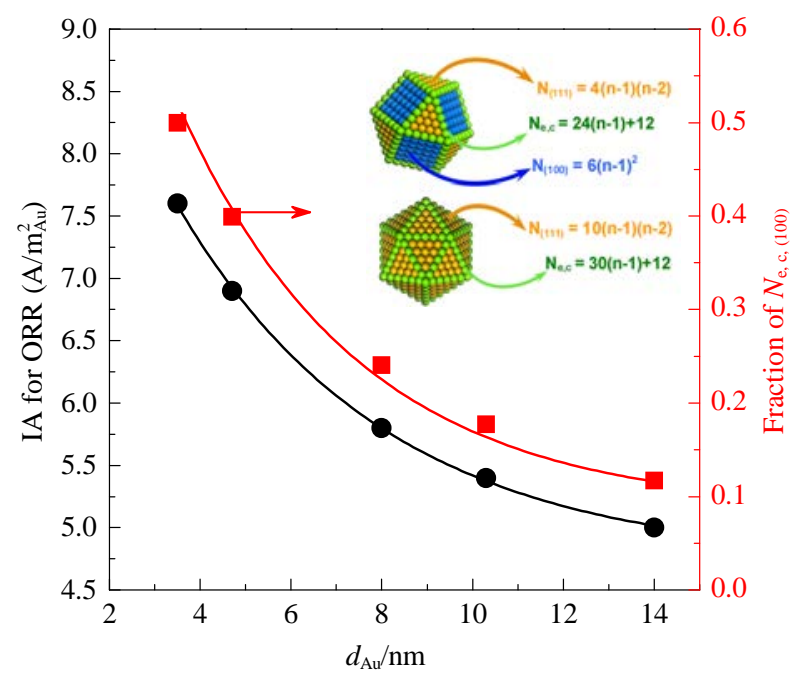

Fig. 5. Correlations between IA toward ORR of the Au- $d$ NPs (circle) and the fraction of surface $\mathrm{Au}$ atoms at corners, edges and (100) facets (square) with the particle size of Au. The schematic illustrations show the calculations for surface $\mathrm{Au}$ atoms at different locations for cuboctahedron (upper) and icosahedron (lower) particles, where $n$ denotes the number of atomic layers for a Au NP.

oms of $\mathrm{Au}$ NPs into two categories according to their CNs [23]: (1) low energy surface atoms of $\mathrm{CN}=9$ at (111) facets, denoted as $N_{(111)}$; (2) high energy surface atoms at corners $(\mathrm{CN}=6)$, edges $(\mathrm{CN}=7)$, and (100) facets $(\mathrm{CN}=8)$, denoted as $N_{\mathrm{c}, \mathrm{e},(100) \text {. }}$ The two sets of data in Fig. 5 correlates, respectively, the IA of $\mathrm{Au}-d$ NPs (left ordinate) and the fraction of $N_{\mathrm{c}, \mathrm{e},(100)}$ (right ordinate) with the $\mathrm{Au}$ particle size (d). Evidently, the fraction of high energy surface Au atoms varies essentially parallel with IA in response to the size change of Au NPs. This is the first time, to the best of our knowledge, to demonstrate that the size-dependent catalytic activity of Au for ORR is closely associated with the variation in the energy state (coordination state) of the surface Au atoms.

It has been theoretically predicted that the surface electronic structure would be significantly influenced by the coordination number of surface metal atoms [38-40]. We measured the surface electronic structure (described in terms of d-band center) of Au NPs by using high-resolution valence-band XPS, a methodology described previously [23]. The results allow us to directly correlate the size-dependent catalytic activity of $\mathrm{Au}$ NPs for ORR with the variations in the surface electronic structure of Au NPs. As summarized in Fig. 6, the intrinsic activity of $\mathrm{Au}$ NPs increased linearly with the d-band center energy, that is, a Au NP having a higher d-band center energy would show a higher IA for ORR in alkaline electrolyte although more data is needed to further solidify this conclusion.

It is well established that the metal d-band center energies would be correlated with the adsorbate-metal interaction [41-43]. A higher d-band center energy would lead to a stronger binding of the adsorbate at the metal surface $[3,44]$. For Pt catalyst, a high d-band center would induce too strong adsorption of $\mathrm{O}$ and $\mathrm{OH}$ species whereas Pt-based alloy catalysts with a much lower Pt d-band center (e.g., PtNi, PtFe) could result in weaker Pt-O interaction and higher activity for ORR 


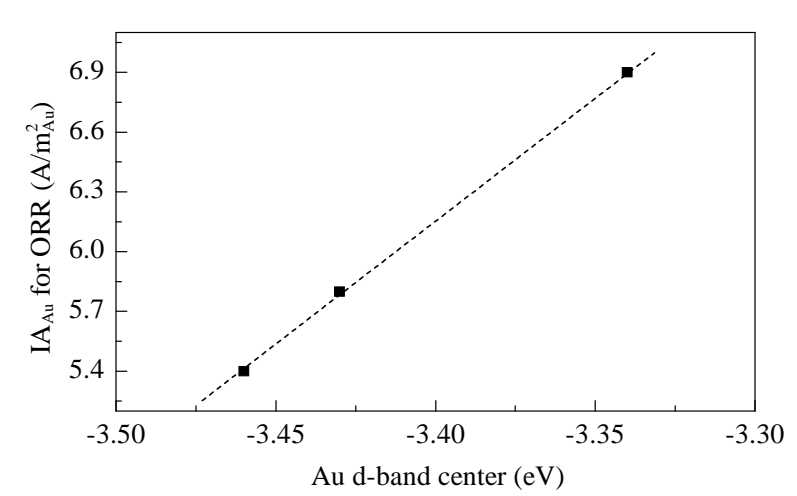

Fig. 6. Correlation between $\mathrm{IA}_{\mathrm{Au}}$ of $\mathrm{Au}-d / \mathrm{C}(d \geq 4.7 \mathrm{~nm})$ catalysts and the Au d-band center energy.

[3]. However, this is not the case for ORR on Au NPs which bind oxygen too weakly because the ORR on Au is actually limited by the transfer of electrons to adsorbed oxygen molecules [11,34]. Due to their higher d-band center energies and consequently higher tendency to form stronger $\mathrm{Au}-\mathrm{O}$ bond, the smaller $\mathrm{Au}$ NPs would promote more effectively the transfer of electrons to the oxygen molecules, thus making ORR kinetically more favorable. To the best of our knowledge, this is the first time to clearly correlate the experimentally determined d-band center energies of Au NPs with their catalytic activity in electrocatalysis.

\section{Conclusions}

This work demonstrates the structure-sensitive nature of ORR in alkaline electrolyte using a series of nearly monodisperse Au NPs, with their particle sizes varied in the range of 3 to $14 \mathrm{~nm}$ using PVP as the only stabilizer and their internal crystal structures specified mainly ( $\geq 82 \%$ ) in the five-twinned decahedral and icosahedral shapes. It is found that the $\mathrm{Au}$ activity for ORR strongly correlates with the $\mathrm{Au}$ particle size. Smaller Au NPs are intrinsically more active though the variation in Au size has no influence on the mechanism of ORR. Also, it uncovers for the first time that the Au activity for ORR correlates well with the experimentally determined surface electronic structure (d-band center). It is anticipated that these findings could have important impact on the design and synthesis of high performance metal catalyst for fuel cells and other applications.

\section{References}

[1] Bron M.J Electroanal Chem, 2008, 624: 64

[2] Stamenkovic V R, Mun B S, Arenz M, Mayrhofer K J J, Lucas C A, Wang G, Ross P N, Markovic N M. Nat Mater, 2007, 6: 241

[3] Stamenkovic V, Mun B S, Mayrhofer K J J, Ross P N, Markovic N M, Rossmeisl J, Greeley J, Norskov J K. Angew Chem, Int Ed, 2006, 45: 2897

[4] Kuai L, Geng B, Wang S, Sang Y. Chem-Eur J, 2012, 18: 9423

[5] Kuai L, Yu X, Wang S, Sang Y, Geng B. Langmuir, 2012, 28: 7168

[6] Adzic R R, Markovic N M, Vesovic V B. J Electroanal Chem, 1984, 165: 105

[7] Strbac S, Adzic R R. J Electroanal Chem, 1996, 403: 169
[8] Tang W, Lin H F, Kleiman-Shwarsctein A, Stucky G D, McFarland E W. J Phys Chem C, 2008, 112: 10515

[9] Wang S, Kuai L, Han X, Geng B. CrystEngComm, 2012, 14: 6581

[10] Hernandez J, Solla-Gullon J, Herrero E, Aldaz A, Feliu J M. J Phys Chem C, 2007, 111: 14078

[11] Chen W, Chen S. Angew Chem, Int Ed, 2009, 48: 4386

[12] Lee Y, Loew A, Sun S. Chem Mater, 2009, 22: 755

[13] Sarapuu A, Nurmik M, Maendar H, Rosental A, Laaksonen T, Kontturi K, Schiffrin D J, Tammeveski K. J Electroanal Chem, 2008, 612: 78

[14] Jirkovsky J S, Halasa M, Schiffrin D J. Phys Chem Chem Phys, 2010, 12: 8042

[15] Zhang G-R, Xu B-Q. Nanoscale, 2010, 2: 2798

[16] Roduner E. Chem Soc Rev, 2006, 35: 583

[17] Phala N S, van Steen E. Gold Bull, 2007, 40: 150

[18] van Bokhoven J A, Miller J T. J Phys Chem C, 2007, 111: 9245

[19] Erikson H, Juermann G, Sarapuu A, Potter R J, Tammeveski K. Electrochim Acta, 2009, 54: 7483

[20] Tsunoyama H, Ichikuni N, Sakurai H, Tsukuda T. J Am Chem Soc, 2009, 131: 7086

[21] Villa A, Wang D, Su D S, Prati L. ChemCatChem, 2009, 1: 510

[22] Yang X W, Zhang G R, Li Y X, Xu B Q. Acta Phys-Chim Sin (杨新伟, 张 贵荣, 李永绣, 徐柏庆. 物理化学学报), 2009, 25: 2565

[23] Zhang G-R, Zhao D, Feng Y-Y, Zhang B, Su D S, Liu G, Xu B-Q. ACS Nano, 2012, 6: 2226

[24] Feng Y Y, Ma J H, Zhang G R, Zhao D, Xu B Q. Chin J Catal (冯媛媛, 马俊红, 张贵荣, 徐柏庆. 催化学报), 2009, 30: 776

[25] Feng Y-Y, Ma J-H, Zhang G-R, Liu G, Xu B-Q. Electrochem Commun, 2010, 12: 1191

[26] Feng Y-Y, Zhang G-R, Ma J-H, Liu G, Xu B-Q. Phys Chem Chem Phys, 2011, 13: 3863

[27] Bard A J, Faulkner L R. Electrochemical Methods: Fundamentals and Applications. 2nd Ed. New York: Wiley, 2000

[28] Trasatti S, Petrii O A. Pure Appl Chem, 1991, 63: 711

[29] Gorshkov V, Zavalov A, Privman V. Langmuir, 2009, 25: 7940

[30] Lim B, Wang J, Camargo P H C, Cobley C M, Kim M J, Xia Y. Angew Chem, Int Ed, 2009, 48: 6304

[31] Mohr C, Hofmeister H, Claus P. J Catal, 2003, 213: 86

[32] Koga K, Sugawara K. Surf Sci, 2003, 529: 23

[33] Xia Y, Xiong Y, Lim B, Skrabalak S E. Angew Chem, Int Ed, 2009, 48: 60

[34] Schmidt T J, Stamenkovic V, Arenz M, Markovic N M, Ross P N. Electrochim Acta, 2002, 47: 3765

[35] Varcoe J R, Slade R C T, Wright G L, Chen Y.J Phys Chem B, 2006, 110: 21041

[36] Vielstich W, Lamm A, Gasteiger H A. Handbook of Fuel Cells Fundamentals Technology and Applications. Vol. 2. New York: Wiley, 2003

[37] Montejano-Carrizales J M, Aguilera-Granja F, Moran-Lopez J L. Nanostruct Mater, 1997, 8: 269

[38] Hammer B, Nielsen O H, Norskov J K. Catal Lett, 1997, 46: 31

[39] Pedersen M O, Helveg S, Ruban A, Stensgaard I, Laegsgaard E, Norskov J K, Besenbacher F. Surf Sci, 1999, 426: 395

[40] Tritsaris G A, Greeley J, Rossmeisl J, Norskov J K. Catal Lett, 2011, 141: 909

[41] Hammer B, Norskov J K. Nature, 1995, 376: 238

[42] Greeley J, Norskov J K, Mavrikakis M. Ann Rev Phys Chem, 2002, 53: 319

[43] Kibler L A, El-Aziz A M, Hoyer R, Kolb D M. Angew Chem, Int Ed, 2005, 44: 2080

[44] Norskov J K, Abild-Pedersen F, Studt F, Bligaard T. Proc Natl Acad Sci USA, 2011, 108: 937 


\title{
Graphical Abstract
}

Chin. J. Catal., 2013, 34: 942-948 doi: 10.1016/S1872-2067(12)60546-4

\section{Nano-size effect of Au catalyst for electrochemical reduction of oxygen in alkaline electrolyte}

\section{ZHANG Gui-Rong, XU Bo-Qing*}

Tsinghua University

This work provides a clear demonstration of the structure-sensitive nature of $\mathrm{Au}$ for oxgen reduction reaction (ORR) in alkaline electrolyte using a series of nearly monodisperse Au nanoparticles, with their particle sizes varied in the range of 3 to $14 \mathrm{~nm}$ using PVP as the only stabilizer.

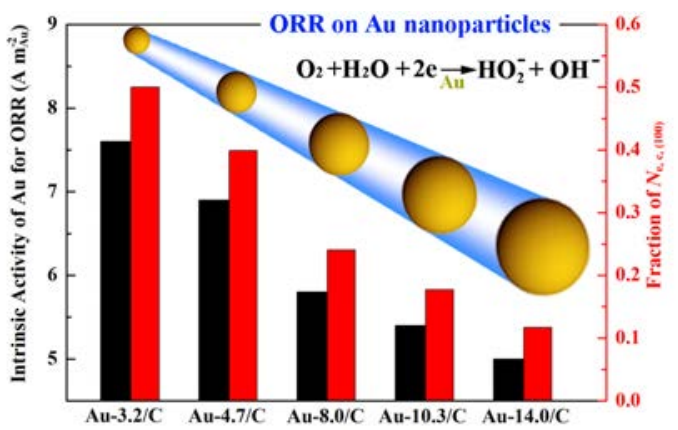

\section{Au催化剂对于碱性电解质中氧气电化学还原反应的纳米尺寸效应}

\author{
张贵荣，徐柏庆 ${ }^{*}$ \\ 清华大学化学系, 有机光电子与分子工程教育部重点实验室, 北京100084
}

\begin{abstract}
摘要：使用旋转电极技术考察了一系列碳载金纳米颗粒(颗粒平均尺寸处在3 14 nm)在碱性电解质 $(0.5 \mathrm{~mol} / \mathrm{L} \mathrm{KOH}$ )中对氧还原 反应的催化行为. 随着金纳米颗粒尺寸由 $14 \mathrm{~nm}$ 下降至 $3 \mathrm{~nm}$, 其对氧还原反应的本征活性和质量比活性均呈现持续走高趋势; 但 金颗粒的纳米尺寸对氧还原反应的机理及分子氧还原过程中的电子转移数目并无显著影响. 使用高分辨透射电镜技术表征了金 纳米颗粒的形貌, 通过对金颗粒表面不同位置原子的比例进行估算, 发现金颗粒表面高能原子所占比例与金对氧还原反应的本征 活性密切相关, 表明高能表面原子决定着金催化剂对氧还原反应的本征活性. 此外, 还将金纳米颗粒对氧还原反应的本征催化活 性与其表面电子结构进行了关联.
\end{abstract}

关键词: 金纳米颗粒; 尺寸效应; 氧还原反应; 表面电子结构; 碱性电解质

收稿日期: 2013-01-11. 接受日期: 2013-02-15. 出版日期: 2013-05-20.

*通讯联系人. 电话: (010)62792122; 传真: (010)62771149; 电子信箱: bqxu@mail.tsinghua.edu.cn

基金来源：国家自然科学基金(21033004); 国家重点基础研究发展计划(2013CB933103).

本文的英文电子版由Elsevier出版社在ScienceDirect上出版(http://www.sciencedirect.com/science/journal/18722067). 